"This is a post-peer-review, pre-copy edited version of an extract/chapter published in Duggan, M. Revisiting the 'Ideal Victim'. Details of the definitive published version and how to purchase it are available online at:

https://policy.bristoluniversitypress.co.uk/revisiting-the-ideal-victim"

\title{
Chapter title: The lived experiences of veiled Muslim women as 'undeserving' victims of Islamophobia
}

\author{
Irene Zempi
}

\section{$<1>$ Introduction}

Following the terrorist attacks of $9 / 11$ and $7 / 7$, and more recently the ISIS-directed attacks in France, Germany and Belgium, the religion of Islam is associated with violence, religious fundamentalism and the global 'war on terror'. In this context, the wearing of the niqab (face covering, hereafter called the 'veil') is perceived as the key visual symbol of Islam in the West. Typically, media discourses about Islamist extremism are illustrated by the image of a Muslim woman in full veil. Through her clothing, this female figure is used to illustrate the 'abnormal', a 'stranger among us', an extreme belief system, embodying the potential threat of terrorist attack (Meer, Dwyer, and Modood, 2010). The wearing of the veil is also seen as a 'threat' to notions of integration and national cohesion as well as a visual embodiment of gender oppression and gender inequality.

According to Perry (2014), the controlling images of veiled Muslim women render them especially attractive and available targets for hate crime. Indeed, the research literature demonstrates that veiled Muslim women are particularly vulnerable as targets of Islamophobic attacks (see, for example, Allen, Isakjee and Young, 2013; Awan and Zempi, 2016; Githens-Mazer and Lambert, 2010; Wing \& Smith, 2006; Zempi and Chakraborti, 2014). The underpinnings of Islamophobic violence are the invocation of negative images and stereotypes associated with veiled Muslim women. At the same time, their dress code identifies them from non-Muslims and to this end, marks them as 'visible' targets of Islamophobic hate crime (Haddad, 2007). 
Despite their vulnerability to Islamophobic hate crimes, veiled Muslim women are unlikely to be perceived as innocent victims worthy of our sympathy and support; rather, they are less valued and thus less protected in comparison to 'ideal victims' (Jiwani, 2005). Veiled Muslim women might be denied the 'ideal victim' identity due to the criminalisation of the veil, especially in light of the banning of the veil in European countries such as France and Belgium. Additionally, they might be denied the 'ideal victim' identity in light of national and international events whereby Islam and Muslims are demonised by political rhetoric and state policies. Against this background, veiled Muslim women are seen as hate crime victims on the margins. Mason (2014) states that victims of hate crime on the margins struggle to engender compassionate emotion for their plight and, hence, fail to convince others that they are undeserved targets of harm that is sufficiently serious to warrant collective concern. Hate crime victims on the margins are branded as 'illegitimate' due to insufficient empirical credibility and their subsequent unheard claims of vulnerability, their extra-marginal position or ambiguous moral status (Williams and Tregidga, 2014). Drawing on empirical research, the chapter demonstrates the implications of the label of 'undeserving victims' for veiled Muslim women who experience Islamophobic hate crime.

\section{$<1>$ Stigmatisation of veiled Muslim women}

As Carrabine et al. (2009) observe, some victims enjoy a higher status in the crime discourse and their victimisation experiences are taken more seriously than others. According to Christie (1986), the status of 'ideal victim' is defined in the following way: "By "ideal victim" I have ... in mind a person of a category of individuals who - when hit by crime - most readily are given the complete and legitimate status of being a victim'. The ideal victim is one who is judged to be weak, vulnerable, innocent, respectable and blameless for their victimisation. In contrast, victims who are judged to be troublesome, distasteful, trivial or engaged in risky behaviour are generally considered to be 'non-ideal victims' (Mason, 2014).

Carrabine et al. (2009) point out that this hierarchy of victimhood stems from notions of 'deserving' and 'undeserving' victims. In this regard, there is a nexus between sympathy and the ideal victim. The literature (Aradau, 2004; Baier, 1994; 
Nussbaum, 2001; Walklate, 2011) demonstrates that deserving victims are those who are capable of generating sentimental emotions such as feelings of sympathy, compassion or pity for the harm inflicted upon them. In other words, deserving victims appear to generate public sympathy for their victimisation. They are seen as innocent victims who deserve help, care and compassion. In contrast, undeserving victims do not generate such sentimental emotions as they are seen as blameworthy for their victimisation; to this end, they deserve the suffering since they have brought the suffering on themselves.

This illustrates a dichotomy between 'innocent' and 'blameworthy' victims. Typically, non-ideal victims are judged to be blameworthy because somehow they were 'asking for it' by engaging in risky or immoral behaviour. From this perspective, the characteristics or behaviour of individual victims can act as precipitating factors in a crime event. In this case, the notion of victim precipitation becomes shorthand for 'victim blaming' (Carrabine et al., 2009). Veiled Muslim women who experience hate crime are often seen to be blameworthy for their victimisation. In this regard, it is important to consider the common stereotypes surrounding the wearing of the veil in the West. Bullock and Jafri (2002: 36) highlight three 'personas' that Muslim women are thought to occupy in the popular imagination, and thus define what Muslim women 'are supposed to be and do': the first is the 'harem belly-dancer character,' the mysterious and sexualized woman of the 'Orient'; the second is 'the oppressed Muslim woman', and, finally, there is the 'militant Muslim woman'.

Veiled Muslim women are constructed as racialised, exotic 'Others' who do not fit the Western ideal of womanhood (Perry, 2014). At the same time, they are likely to be stigmatised due to their affiliation with Muslims, a group that is often associated with negative stereotypes, attitudes, and perceptions (Poynting and Mason, 2007). Moreover, the wearing of the veil signals Muslim women as docile, oppressed, submissive and passive. From this perspective, the wearing of the veil is understood as an oppressive and subordinating practice, which is not 'welcome' in the West (Chakraborti and Zempi, 2012). Mahmud and Swami (2010) found that veiled Muslim women are considered unattractive and less intelligent, whilst Unkelbach et al. $(2008,2009)$ found that Muslim women wearing the hijab (headscarf) were 
subjected to more aggressive behaviour in a shooter bias paradigm than non-hijabi targets.

While the veil is taken as a sign of gender inequality and oppression, it is also taken as a sign of Islamist terrorism. Even though Muslim females are stereotypically seen as oppressed, while Muslim males are stereotypically seen as being aggressive, belligerent, and hostile, it should be noted that Muslim women are not free from the common Muslim stereotypes, as Muslims in general are portrayed as evil, barbaric, backwards, terrorists, religious fundamentalists, and uncivilized (Cole and Ahmadi, 2003; Haddad, 2007). As Perry (2014) points out, if veiled Muslim women are not characterised as exotic, or as oppressed, they are represented as dangerous and threatening; this is fuelled by the controlling image of 'Muslim as terrorist.' To this end, veiled Muslim women are represented as 'agents' of terrorism or as the tools of Islamist terrorism aiming to infiltrate the West (Jiwani, 2005). From this perspective, Muslim women are not seen as 'real' women or mothers like Western women; rather they are seen as 'mothers of suicide bombers' (Perry, 2014). Moreover, veiled Muslim women might be seen as 'terrorist' bodies on the basis that their face is covered and to this end, the veil could be used as a camouflage for a terrorist (Zempi and Chakraborti, 2014).

Finally, veiled Muslim women are feared and reviled on the same basis as all Muslims but they are also 'othered' because of the visibility of the veil. Indeed, it is well established in the literature that there is a significant relationship between being visible as a Muslim and experiencing Islamophobic hate crime (Allen, 2010). If the markers of Islam (for example, a Muslim dress or a Muslim name) are absent, 'passing' as a non-Muslim is possible for those without conspicuous Muslim names or dress, and those who do not 'look like' a Muslim (Garner and Selod, 2015). As such, being visually identifiable as a Muslim has been found to be the most powerful antecedent to negative behaviours against Muslims (Allen and Nielson, 2002). According to Goffman (1963), individuals whose stigma is 'visible' experience more hostility than individuals with 'concealable' stigmas. Given that the majority of Muslim women do not wear the veil, those Muslim women who do wear it are likely to be perceived as having a 'controllable' stigma for actively choosing to wear it (Ghumman and Ryan, 2013). Based on Goffman's (1963) approach, individuals who have such 'controllable' 
stigmas are more likely to be subjected to stigmatisation based on the premise that they are perceived as being 'responsible' for their own condition. In this respect, when Muslim women choose to wear the veil, they are seen as purposefully isolating themselves and rejecting Western values. From this perspective, the wearing of the veil is seen as a sign of self-segregation; it is thought to hinder face-to-face communication, which is necessary in an open society as well as broader engagement with non-Muslims. As such, veiled Muslim women 'deserve' to be punished for choosing to isolate themselves from wider society but do not 'deserve' our sympathy or support.

Taken in isolation or collectively, these stereotypes are commonly presented as justification for expressions and acts of hostility towards veiled Muslim women as a means of responding to the multiple 'threats' of the veil as a symbol of gender oppression, self-segregation and Islamist terrorism. These stereotypes also mark Muslim women as 'blameworthy' victims of Islamophobic hate crime.

\section{$<1>$ State policies criminalising the wearing of the veil}

The construction of the veil exclusively through the lens of Islamist terrorism, gender oppression and self-segregation has triggered a spate of national and international reforms focused on the criminal law, which are used to justify state restrictions on the wearing of the veil in public places (Fredette 2015). In 2010, France became the first European country to ban the wearing of the veil in public whilst in 2011, Belgium followed suit. Nicolas Sarkozy, then president of France, stated that veils oppress women and were 'not welcome' in France. In 2014, the European Court of Human Rights (ECHR) upheld the veil ban in France, declaring that the idea of 'living together' was the 'legitimate aim' of the French authorities, thereby lending support to perceptions of the veil as a 'threat' to national cohesion and integration. In 2016, French Riviera mayors introduced a ban on burkinis (full-body Islamic swimsuits). French Prime Minister Manuel Valls stated that burkinis were 'the affirmation of political Islam in the public space'. Although the 'burkini ban' has now been lifted (after France's highest administrative court overruled the law), some mayors refuse to lift the restrictions. In some parts of Italy, local authorities have also banned burkinis. 
Germany has no national law restricting the wearing of Muslim veils, but half of Germany's 16 state governments have outlawed the wearing of both headscarves and veils by teachers. In December 2016, German Chancellor Angela Merkel called for a veil ban wherever legally possible for the 'good of Germany'. She stated: 'Show your face. The full covering is not permissible and should be banned'. Several parts of Catalonia in Spain have laws against the wearing of the veil in public. Although Spain's Supreme Court has overturned the ban ruling that it 'limits religious freedom', certain areas continue to enforce the veil ban. In this case, they use the 2014 ECHR ruling that banning the veil does not breach human rights. In January 2017, the ruling coalition in Austria agreed to prohibit the wearing of the veil in public spaces as well as a general ban on state employees wearing the headscarf. In the Netherlands, there is a partial ban on the veil, which means that Muslim women cannot have their faces covered in schools, hospitals and on public transport.

The UK does not have a ban on Islamic dress but schools can decide their own dress code and prevent students from wearing veils. In January 2016, the chief inspector for Ofsted instructed other inspectors to downgrade institutions where they believed that the wearing of the veil - by students or teachers - hindered 'positive social interaction'. At the same time, a number of British politicians have expressed strong feelings of antipathy towards the wearing of the veil in public in the UK. For example, in September 2013, the then Home Office Minister Jeremy Browne called for a 'national debate' about banning the veil in schools. Nick Clegg, then Deputy Prime Minister, suggested he may support banning the veil in classrooms whilst the then Prime Minister, David Cameron stated that Muslim women could be banned from wearing veils in schools, courts and other institutions. UKIP has systematically argued for banning the veil on the basis that it is a symbol of an 'increasingly divided Britain', gender oppression and a security threat. In July 2010, a YouGov survey found that 67 per cent of the public supported a veil ban in public in the UK. A further YouGov survey, in August 2016, found that banning the veil ban continued to be a popular policy in the UK. Specifically, a majority of the public (57\%) supported a veil ban in public in the UK.

Chakraborti and Zempi (2013) argue that by making the wearing of the veil a criminal offence, this law promotes a climate of intolerance, even hostility, thereby 
legitimising violence targeted at veiled Muslim women - be it in terms of violation of human rights, discrimination, harassment on the street or victim-blaming attitudes. The veil ban promotes this negative discourse not only in those countries where the ban has been enforced but also in other European countries such as the UK, where it is still legal to wear the veil. This finding is illustrative of the domino effect of European policy, whereby events in one European country can influence public opinion in its neighbouring states (Chakraborti and Zempi, 2013). From this perspective, the veil ban justifies and rationalises a negative discourse that makes Muslim women blameworthy as victims of Islamophobic hate crime, both nationally and internationally.

As we see in what follows, stereotyping of the veil has serious implications on the lived experiences of veiled Muslim women as victims of Islamophobic hate crime and the ways in which they are dealt with by the criminal justice system. This in turn has led to unwillingness amongst some victims to engage with the police and courts.

\section{$<1>$ The research study}

The aim of this study was to examine the lived experiences of Muslim women who wear the niqab in the UK. Specifically, this was a qualitative study that included 60 indepth interviews and 20 focus groups with niqab-wearing women in Leicester between 2011 and 2012. All the participants wore full-length jilbabs (long robe) accompanied with hijabs (headscarves) and niqabs (face veils), mostly in black, and thus in their public encounters they were visibly identifiable as Muslim women. Participation in the study was voluntary. Prospective participants were identified through local Muslim organisations including mosques, Muslim schools and Islamic centres, as well as local Muslim university student societies, and Muslim women's groups. Participants unaffiliated to any local Muslim organisations or groups were also recruited through snowball sampling. Participants' real names have been replaced by pseudonyms in order to maintain their anonymity.

\section{$<2>$ Experiences of Islamophobia}

Throughout individual and focus group interviews, participants reported that suffering Islamophobic hate crime was 'part and parcel' of being a veiled Muslim woman in the UK. They described incidents of attempted and/or actual physical assaults (including 
taking the veil off), pushing, shoving, being spat at and even incidents where passing vehicles had attempted to run them over. They also described incidents where people on the street or from moving cars had thrown eggs, stones, alcohol, water bombs, bottles, take-away food and rubbish at them. In addition, verbal abuse from strangers in public (including streets, parks, shopping centres and public transport) was a common experience amongst participants. They also reported experiencing intimidation and harassment on social networking sites such as Facebook, Twitter and MySpace, as well as blogs and chat rooms. Underlying these incidents of intimidation, violence and abuse was a clear sense of Islamophobic sentiments, and this was made apparent through the language used by the perpetrators that signified their motivations for the attack. For example, participants had been called names such as 'Muslim terrorists', 'Muslim bombers' and 'Suicide bombers', which indicate the perpetrators' perceptions of veiled Muslim women as a security or terrorist 'threat'.

Moreover, participants reported being used as a form of 'entertainment'. For example, they were called names such as 'Ninja', 'Catwoman', 'Batman', 'Darth Vader', 'Ghost woman', 'Bin bag', 'Letterbox', 'Postbox', 'Witch' and 'Walking Coffin'. They were also subjected to swearing such as 'Fucking freak', 'Muslim bitch' and 'Muslim whore'. 'Low-level' incidents such as persistent staring, being ignored and/or avoided by people, being laughed at, being monitored at shops and being stalked by strangers on the street were common themes which underpinned participants' accounts as they described their experiences of Islamophobic hate incidents in public.

Ultimately, these manifestations of Islamophobic hate crime were not 'oneoff' incidents; rather there was always the reality, the fear, and the expectation for another attack. This paints a picture of an everyday phenomenon, which can be better understood as a process rather than as incidental occurrences. Further qualitative research into the experiences of Muslim women who wear the veil has been conducted in five European countries, Belgium, Denmark, France, the Netherlands, and the UK (Brems, 2014). The data show very strong similarities such as harassment and abuse of veiled Muslim women by strangers in public places. For example, veiled Muslim women in the Netherlands reported regularly being confronted with people who scolded, insulted or spat at them (Moors, 2009; 2014). Some women also mentioned being physically threatened, with cars attempting to hit them, people 
throwing things at them or trying to pull off the niqab (Moors, 2009; 2014). Echoing these experiences, veiled Muslim women in the UK and France described a stream of violent insults in public places including being violently pushed, spat on, and having their veils pulled off (Boutelja, 2011).

In the present study, participants argued that the typical perpetrator was white male; however, it was evident that the perpetrator could be anyone such as women, members of ethnic and racial minorities (including EU nationals) as well as children.

For me it can be anybody. At the beginning it was mostly men but now I get a lot of abuse from women as well. Women can be very offensive and they will say and do horrible things to us. (Raja)

I was coming here [mosque where the focus group interview took place] and I heard children, they were not all white children, shouting 'There is a ninja in this car' and then they threw snow at my car. (Nisha)

I don't know how other sisters feel but for me Asians are racist as well. I have come across that, the specific comment was 'Bitch take that off your face' and that wasn't from a white person. (Focus group participant)

We have a tough time with Eastern Europeans. Blatant mocking and laughing in our face and all in another language has left us bewildered as well as hurt. (Focus group participant)

Moreover, participants revealed that they had suffered abuse from fellow Muslims. In this context, the abuse came from members of the Muslim community who saw themselves as 'Westernised' or 'non-practising' Muslims.

It's not just about Islamophobia coming from non-Muslims. There are also Muslims who don't like the niqab. They say to me that we shouldn't wear 
it because we give them a bad name. We have it from both sides, Muslims and non-Muslims. (Focus group participant)

In some cases, the abuse came from participants' Muslim family members. Participants explained that some Muslim parents accept and encourage their daughters to wear the hijab but do not like the niqab, viewing the latter as an extreme form of practising Islam. Other Muslim parents were not necessarily opposed to the wearing of the veil itself but fear for their daughters' safety.

How can I blame a person on the street when I've had problems from my own [Muslim] family? How do I have the right to wear it in public when my whole family doesn't agree with it? (Focus group participant)

For those participants who had converted to Islam, family members objected vehemently to becoming Muslims, let alone supporting their decision to wear the veil. Throughout interviews and focus group discussions, it was clear that those participants who had converted to Islam often felt obliged to hide the fact that they wore the veil in order to 'keep the peace' with their family whilst others were sometimes forced to cut off communication with their family due to intense disagreements about their decision to convert to Islam and/or wear the veil.

When I visit my [non-Muslim] parents I take my niqab off and I keep the hijab on, but even with the hijab they are not happy. (Zoe)

My parents don't like the fact that I'm wearing a niqab. My mum especially, she finds it hard to deal with it so when I go to meet them I take it off out of respect so that they don't feel uncomfortable with me in public. (Focus group participant)

With respect to the relationship between perpetrators and victims, participants explained that they were usually targeted by strangers on the street. This is consistent with the views of Githens-Mazer and Lambert (2010) who found that manifestations 
of Islamophobia are invariably random in nature on the basis that veiled Muslim women are randomly targeted when they are seen in public. According to Chakraborti and Garland (2015), hate crimes are often committed by relatively 'ordinary' people in the context of their everyday lives. Iganski and Levin (2004) found that hate crime is often perpetrated by 'ordinary' members of the community rather than right-wing extremists.

Participants argued that their confidence had been severely affected as a result of their recurring experiences of targeted hostility, with many using terms such as feeling 'worthless', 'unwanted' and that they "didn't belong". Participants also reported feeling 'unwelcome' in this country.

Everyone thinks we are the enemy. I feel that I don't have the right to be here. It crushes my self-esteem. (Parveen)

We feel like social lepers that no one wants to engage with. (Maryam)

We've been made to feel that we are totally unwanted. It's like we are a virus to the community. (Focus group participant)

We don't belong anywhere. We have no place. It's like we are not wanted anywhere. (Focus group participant)

Participants also described feelings of shame, self-doubt and guilt. They referred to incidents of Islamophobic victimisation as 'humiliating' and 'embarrassing'. The following comments help to convey the sense of humiliation and embarrassment that veiled Muslim women might feel when experiencing Islamophobic victimisation in public, often in view of people passing by who do not intervene to help them.

I feel humiliated and I feel totally alone even though there are so many people around. If somebody would speak up and say 'Leave her alone, it is up to her how she dresses' but nobody has ever come to my defence.

(Kalila) 
It is awful because when they do it, they all do it publicly. There are witnesses all over the place. People are looking but nobody does anything. Nobody says 'It is wrong'. (Karima)

When people abuse me I feel intimidated because I don't know where to go and there's no one actually there to help me. (Aliyah)

Relatedly, the fact that no one would intervene to help them had culminated in 'blaming the victim'. In this sense, participants were made to feel responsible and 'guilty' for being attacked on the basis that they were 'different' and 'Muslim'. Concurrently, self-blaming was a way of making sense of their victimisation. The notion of self-blame is illustrated in the following comments:

When you have someone abusing you like that, you automatically feel "It's my fault because I'm wearing this". (Huda)

We feel we are causing a crime and we are not. We are just covering ourselves; that is not criminal. Well now it is criminal in France but it's not in this country. (Focus group participant)

Participants reported that 'nobody cared' about their victimisation and as such, they were 'shocked' that this study was interested in their experiences.

Nobody takes any action about it, nobody really cares. I am surprised you do. We didn't know that there was support until you mentioned it to us. (Samina)

We feel nobody wants to listen to us. I was shocked that you'd come to hear us. We feel that nobody wants to hear us, to see us, people don't look at us as humans anymore, they treat us like we are sub-human.

(Focus group participant) 
In some cases, bystanders 'jumped on the bandwagon' and started abusing them as well.

I got on the bus and a woman with a pushchair called me a 'Dirty Muslim' and spat at me, and then other people on the bus started calling me names too. The bus driver did not intervene. (Sabirah)

Once I was in town [Leicester city centre] and somebody pulled my niqab off. He did it on purpose. Nobody stepped in to help me. People tend to look away. But l've had incidents where other people joined in the abuse. I was verbally abused by a group of white men, I was told "You're a terrorist, go back to your own country!" and then someone walking past said 'I will slit your throat, you Bin Laden bitch'. (Anisa)

\section{$<1>$ Secondary victimisation in the Criminal Justice System}

The majority of participants revealed that they would not normally disclose their experiences of Islamophobic victimisation to anyone including family, friends or the police. They felt stigmatised by such incidents and this feeling was reinforced by previous experiences of being treated insensitively by others. There was also a sense of resignation on the part of participants who had accepted that incidents of Islamophobic victimisation were going to happen as long as they wore the veil. This fact, in combination with feelings of shame and fear of being blamed, had resulted in this victimisation not being disclosed to anyone, as indicated in the quotation below.

Other veiled sisters that I know don't really talk about it. I don't tell anyone and same with everyone else I think. It is embarrassing so I just forget about it. (Jamilah) 
Sisters feel helpless and in a state of despair, and then having to report to the police or give evidence to court, this only exacerbates our plight. We keep quiet to avoid further abuse. (Rehana)

Disclosure of victimisation can make veiled Muslim women vulnerable on the basis that they may encounter hostility, disbelief or judgmental attitudes and this can have a harmful effect upon them to the extent of revictimising them. Indeed, a barrier to reporting their experiences of Islamophobic victimisation to the authorities was the fact that participants feared victim-blaming attitudes, insensitive questioning and hostile responses from criminal justice agents, particularly the police and the courts. Specifically, some participants feared that they would become the ones under investigation or on trial on the basis of wearing the veil. In some cases, they feared that they would be seen as blameworthy for their victimisation for wearing the veil. According to Wolhuter (et al., 2009), in addition to the suffering caused by Islamophobic incidents, there is the possibility of further suffering caused by the way in which veiled Muslim women are treated within the criminal justice system. Victimblaming attitudes as well as discriminatory policies and practices that result in additional trauma and further violation of victims' rights could be understood as 'revictimisation' or 'secondary victimisation' (Cambell and Raja, 2005). Williams (1999) highlights the added impact of secondary victimisation through the police investigation and court processes. Along similar lines, Dunn and Shepherd (2006) observe that the emotional impact of giving evidence is likely to be particularly difficult for witnesses who may be vulnerable or intimidated. Certainly, the way that the police conduct the initial interview appears to be significant. Questions that suggest that victims provoked the attack by wearing the veil can evoke feelings of guilt and self-blame that impair the victim's recovery process and discourage disclosure. Likewise, a lack of respect for veiled Muslim women's cultural and religious needs, such as failing to provide a female officer or Muslim women being forced to take the veil off in court, could also cause the victim further suffering which amounts to secondary victimisation. 
It wasn't easy giving a statement to a male officer. It really made me understand why other sisters don't report it. (Hadiqa)

As victims we feel frightened and intimidated to go through the criminal justice system because we know that the veil will be a problem in court. $A$ lot of sisters are hoping they can live their lives without ever having to contact the police about anything. (Focus group participant)

Most participants were adamant that the police would fail to understand the seriousness of the case, empathise with them and accommodate their religious and cultural needs. The following comments help to illustrate some of the key concerns raised by participants in relation to victim-blaming attitudes and a lack of understanding/empathy within the police service.

The police won't help us. They think we are some kind of monsters. (Nabeeha)

We feel that the police will not take it seriously. They don't understand women in veil anyway so how are they going to deal with this crime? They probably think we shouldn't cover our face anyway. (Focus group participant)

We feel misunderstood by the police. I've got stares from the police as well. I walked past the police and the police officer looked at me thinking 'You are one of the terrorists'. I could tell. (Focus group participant)

As can be seen in the quotations above, there was a lack of confidence in the police, particularly in terms of being treated as a 'suspect community'. The 'low-status, powerless groups' (Reiner, 2010: 93) whom the dominant majority in society see as distasteful occupy the lower end of the dominant end of the hierarchy of victimisation (Carrabine et al., 2009). When members of such groups report a crime to the police, they have to engage in a struggle to have their experiences taken seriously. This has 
led to complaints from these social groups that they are being 'over-policed' as problem populations but 'under-policed' as victims (Carrabine et al., 2009). Allen et al., (2013) found that for many Muslim women there is a very real sense of fear and mistrust in dealing with the police and state agencies, whilst, at the same time, cultural and religious factors combine with that mistrust to create additional obstacles to reporting their experiences to the police.

\section{$<1>$ Conclusion}

Typically, veiled Muslim women are perceived as constituting a 'threat' to society. They are viewed as 'dangerous' in terms of public safety, community cohesion and gender equality, and they are defined as a group of individuals who are distinctly different from 'us'. Bauman (1997) argues that societies have a need to set 'the others' apart - those individuals who do not fit in. This contributes to a polarisation of people into the categories 'us' and 'them'. The 'ideal victim' is described inclusively as one of 'us', symbolising the good, innocent citizen. Since all law-abiding citizens can be exposed to crime, 'victims R us' (Stanko, 2000: 13). A crime victim who lives up to the expected victim role is a deserving victim (Goodey, 2005). In this regard, the fundamental requirement for an individual to be seen as the ideal victim is that they are innocent and blameless - prudent citizens (Garland, 2001). As such, ideal victims are perceived as blameless in relation to their victimisation. This also produces an inclusive victimhood as a result of the underlying assumption that 'it could have been me' (Heber, 2014). However, veiled Muslim women who experience hate crime do not fall into the ideal victim category. For Christie (1986), victims who can be blamed for being victimised are unlikely to be granted ideal victim status. When individuals have a potentially ambiguous status, the audience is unlikely to empathise with them and view them as deserving victims (Heber, 2014). Veiled Muslim women are blamed for their victimisation: had they not wore the veil, they would not have taken the risk of being attacked.

Drawing on individual and focus group interviews conducted with veiled Muslim women, this chapter demonstrated the implications of the label of 'undeserving victims' for veiled Muslim women who experience Islamophobic hate crime. For example, participants described feelings of shame, self-doubt, guilt, 
humiliation and embarrassment; these feelings were exacerbated by the fact that no one would intervene to help them. In some cases, bystanders 'jumped on the bandwagon' and started abusing them as well. Many scholars have used the analogy of the 'little old lady' as the ideal victim. Van Wijk (2013: 160) explains that "Christie's archetypal ideal victim is the 'little old lady', who after having cared for her sick sister, gets robbed by a big and hooded drug addict in clear daylight". Benefiting from victim status, Christie (1986: 27) states that having ideal victim status may help to improve the situation of suffering individuals. The little old lady might benefit in different ways: while she is being victimised, bystanders may intervene and chase off the offender whilst after being victimised she could receive support and justice from criminal justice agencies (Van Wijk, 2013). The data showed that participants sometimes suffered in silence, concealing their experiences of Islamophobic abuse from family and friends as well as the authorities. Based on previous encounters with criminal justice agencies, participants feared that they would encounter hostility, disbelief or judgmental attitudes from the police and/or courts. The perceptions captured by the participants in this study have implications for not only tackling hate crime towards veiled Muslim women but also providing them with support mechanisms and criminal justice responses that eliminate feelings of guilt, shame and self-doubt.

\section{References}

Allen, C. (2010) Islamophobia, Surrey: Ashgate.

Allen, C., Isakjee, A. and Young, O. (2013) Understanding the Impact of Anti-Muslim Hate on Muslim Women, Birmingham: University of Birmingham.

Allen, C. and Nielsen, J. (2002) Summary Report on Islamophobia in the EU after 11 September 2001, Vienna: European Monitoring Centre on Racism and Xenophobia.

Aradau, C. (2004) 'The perverse politics of four-letter words: Risk and pity in the securitisation of human trafficking' Journal of International Studies 33(2): 251-277. 
Awan, I. and Zempi, I. (2016) 'The Affinity between Online and Offline anti-Muslim Hate Crime: Dynamics and Impacts', Aggression and Violent Behaviour 27: 1-8.

Baier, A. (1994) Moral Prejudices: Essays on Ethics. Cambridge, MA: Harvard University Press.

Bauman, Z. (1998) Globalization: The Human Consequences. London: Polity Press. Bouteldja, N. (2011) Unveiling the Truth: Why 32 Muslim Women Wear the Full face Veil in France, London: Open Society Foundations.

Brems, E. (2014) 'Introduction to the volume', in E. Brems (ed.) The Experiences of Face Veil Wearers in Europe and the Law, Cambridge: Cambridge University Press, pp. 1-17.

Bullock, K. and Jafri, G. J. (2002) 'Media (Mis) representations: Muslim women in the Canadian nation' Canadian Women's Studies 20(2): 35-40.

Carrabine, E., Cox, P., Lee, M., Plummer, K. and South, N. (2009) Criminology: A Sociological Introduction, Oxon: Routledge.

Chakraborti, N. and Garland, J. (2014) Hate Crime: Impact, Causes and Responses, London: Sage.

Chakraborti, N. and Zempi, I. (2013) 'Criminalising Oppression or Reinforcing Oppression? The Implications of Veil Ban Laws for Muslim Women in the West' Northern Ireland Legal Quarterly 64(1): 63-74.

Chakraborti, N. and Zempi, I. (2012) 'The Veil under Attack: Gendered Dimensions of Islamophobic Victimisation', International Review of Victimology 18 (3): 269-284. 
Christie, N. (1986) 'The ideal victim', in: E. Fattah (ed.) From Crime Policy to Victim Policy: Reorienting the Justice System, London: Macmillan, pp. 17-30.

Cole, D. and Ahmadi, S. (2003) 'Perceptions and Experiences of Muslim Women who Veil on College Campuses,' Journal of College Student Development 44(1): 47-66.

Dunn, P. and Shepherd, E. (2006) 'Oral Testimony from the Witness's Perspective Psychological and Forensic Considerations': in A. Heaton-Armstrong, E. Shephard, G. Gudjonsson and D. Wolchover (eds) Witness Testimony: Psychological, Investigative and Evidential Perspectives, Oxford: Oxford University Press.

Fredette, J. (2015) 'Becoming a Threat: The Burqa and the Contestation Over Public Morality Law in France', Law \& Social Inquiry 40(3): 585-610.

Garland, D. (2001) The Culture of Control: Crime and Social Order in Contemporary Society, Oxford: Oxford University Press.

Garner, S. and Saher, S. (2015) 'The Racialization of Muslims: Empirical Studies of Islamophobia', Critical Sociology 41(1): 9-19.

Ghumman, S. and Ryan, A. M. (2013) 'Not welcome here: Discrimination towards women who wear the Muslim headscarf', Human Relations 66(5): 671-698.

Githens-Mazer, J. and Lambert, R. (2010) Islamophobia and Anti-Muslim Hate Crime: A London Case Study, London: European Muslim Research Centre.

Goffman, E. (1963) Stigma: Notes on the Management of Spoiled Identity, Englewood Cliffs, NJ: Prentice Hall.

Goodey, J. (2005) Victims and Victimology: Research, Policy and Practice, Harlow: Pearson Education Limited. 
Haddad, Y. (2007) 'The post 9/11 hijab as icon', Sociology of Religion 68(3): 252-67.

Heber, A. (2014) 'Good versus bad? Victims, offenders and victim-offenders in Swedish crime policy', European Journal of Criminology 11(4): 410-428.

Iganski, P. and Levin, J. (2004) 'Cultures of hate in the urban and the rural: assessing the impact of extremist organisations': in N. Chakraborti \& J. Garland (eds.) Rural Racism. Cullompton: Willan, pp.108-121.

Jiwani, Y. (2005) “'War Talk” engendering terror: Race, gender and representation in Canadian print media,' International Journal of Media and Cultural Politics,1(1): 1522.

Mahmud, Y. and Swami, V. (2010) 'The influence of the hijab (Islamic head-cover) on perceptions of women's attractiveness and intelligence', Body Image 7(1): 90-93.

Mason, G. (2014) 'The symbolic Purpose of Hate Crime law: ideal Victims and emotion', Theoretical Criminology 18: 97-92.

Meer, N., Dwyer, C. and Modood, T. (2010) "Embodying Nationhood? Conceptions of British National Identity, Citizenship and Gender in the "Veil Affair," The Sociological Review, 58(1): 84-111.

Moors, A. (2009) 'The Dutch and the Face-Veil: The Politics of Discomfort', Social Anthropology 17(4), 393-408.

Moors, A. (2014) 'Face veiling in the Netherlands: public debates and women's narratives', in E. Brems (ed.) The Experiences of Face Veil Wearers in Europe and the Law, Cambridge: Cambridge University Press, pp. 19-41. 
Nussbaum, M. (2001) Upheavals of Thought: The Intelligence of Emotion, Cambridge, UK: Cambridge University Press.

Perry, B. (2014) 'Gendered Islamophobia: hate crime against Muslim women', Social Identities 20: 74-89.

Poynting, S. and Mason, V. (2007) 'The resistible rise of Islamophobia: Anti-Muslim racism in the UK and Australia before 11 September 2001', Journal of Sociology 43(1): 61-86.

Reiner, R. (2010) The Politics of the Police (4rd Edition), Oxford: Clarendon Press.

Spalek, B. (2006) Crime Victims, Theory, Policy and Practice, Hampshire: Palgrave Macmillan.

Stanko, E. (2000) 'Victims R us', in T. Hope and R. Sparks (eds) Crime, Risk and Insecurity, London: Routledge, pp. 13-31.

Unkelbach, C., Forgas, J.P. and Denson, T.F. (2008) 'The turban effect: The influence of Muslim headgear and induced affect on aggressive responses in the shooter bias paradigm', Journal of Experimental Social Psychology 44(5): 1409-1413.

Unkelbach, C., Goldenberg, L., Müller, N., Sobbe, G. and Spannaus, N. (2009) ‘A shooter bias against people wearing Muslims headgear in Germany', International Review of Social Psychology 22(3-4): 181-201.

Van Wijk, J. (2013) "Who is the 'little old lady' of international crime? Nils Christie's concept of the idea Victim reinterpreted", International Review of Victimology 19(2): 159-179.

Walklate, S. (2011) 'Reframing Criminal Victimization: Finding a Place for Vulnerability and Resilience', Theoretical Criminology 15: 179-94. 
Williams, M. and Tregidga, J. (2014) 'Hate Crime Victimisation in Wales:

Psychological and Physical Impacts Across Seven Hate Crime Victim-Types,' British Journal of Criminology 54(4): 946-967.

Wing, A., and Smith, M. (2006) 'Critical race feminism lifts the veil?: Muslim women, France, and the headscarf ban', U.C. Davis Law Review, 39: 743-786.

Wolhuter, L., Olley, N. and Denham, D. (2009) Victimology: Victimisation and Victims' Rights, Abingdon: Routledge-Cavendish.

Zempi, I. and Chakraborti, N. (2014) Islamophobia, Victimisation and the Veil, Basingstoke: Palgrave Macmillan. 